\title{
Development of transgenic Sorghum bicolor (L.) Moench resistant to the Chilo partellus (Swinhoe) through Agrobacterium-mediated transformation
}

\author{
Savarimuthu Ignacimuthu $u^{1,2^{*}}$ and Antony Premkumar ${ }^{3}$ \\ *Correspondence: entolc@hotmail.com

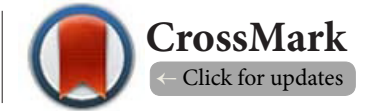 \\ 'Plant Biotechnology Unit, Entomology Research Institute, Loyola College, Chennai 600034, Tamil Nadu, India. \\ ${ }^{2}$ Department of Botany \& Microbiology, College of Science, King Saud University, Riyadh, Kingdom of Saudi Arabia-11451. \\ ${ }^{3}$ Department of Plant Biology and Biotechnology, Loyola College, Chennai 600034, Tamil Nadu, India.
}

\begin{abstract}
An Agrobacterium mediated gene transformation was developed in Sorghum for insect resistance using shoot apices. Sorghum spotted stem borer (Chilo partellus Swinhoe) is an important insect pest of sorghum which causes severe damage in many parts of the world. Sorghum plants were transformed with fully modified synthetic CrylC coding sequences along with $h p t$ and gus genes. The calli developed from shoot apices of APK 1 cultivar were inoculated with Agrobacterium strain. Embryogenic calli from the shoot apices were selected on the medium containing hygromycin B. A total of 76 hygromycin resistant plants were regenerated. PCR was performed to confirm the presence of the Cry $1 C$ gene. All the three putative transformants were found to be positive for the amplification of 1.9 $\mathrm{kb}$ Cry $1 \mathrm{C}$ gene. A similar band was also observed in the positive plasmid control. Southern blot analysis of transformants confirmed integration of $2.9 \mathrm{~kb}$ Cry $1 \mathrm{C}$ coding sequences into the sorghum genome. $\mathrm{S}_{1}$ progeny plants disclosed a monogenic pattern (3:1) of transgene segregation. The efficiency of transformation in our study was between $1.2 \%-3.9 \%$. These transgenic lines were highly resistant to the spotted stem borer Chilo partellus as revealed by insect bioassay with $100 \%$ insect mortality rate.

Keywords: Sorghum (Sorghum bicolor), transgenic crops, insect resistance, GUS expression, Agrobacterium, Cry1C, hpt, chilo partellus
\end{abstract}

\section{Introduction}

Sorghum bicolor L. (Moench) is the fifth most important cereal crop worldwide in production and is unique since it is adapted to semi-arid environments. It is one of the main staple foods of the world's poorest and most food-insecure people, supporting more than $\mathbf{3 0 0}$ million lives in Africa and Asia. It is thought to be $>200$ million years old [1]. The total worldwide production of sorghum is about 60 million tonnes annually from a cultivated area of 46 millions ha. It belongs to the tribe Andropogoneae and the family Poaceae $[2,3]$. Sorghum grain has enhanced protein quality that could contribute significantly to nutritional value of the diets of people and livestock. The plant stem and foliage are used for green chop, hay, silage, pasture and hut making. The sorghum flour is also used as food for infants [4]. It has been used for various food products like roti (flat bread), bhakri (stiff roti) and porridge. It is also used in common foods such as traditional breakfast [5]. It also represents an ideal bio-energy crop, as grain quality is now considered less important, and concerns about the environmental cost of highinput agriculture and food security grow. The lower need for fertilizers and pesticides may make it an ecologically attractive crop, especially when combined with conservation-agriculture production systems.

Insect pest infestation acts as a serious limiting factor on crop yield and affects productivity of sorghum. The use of genes that encode insecticidal proteins in transgenic crops has the potential to benefit agricultural crop production, the environment, and the consumer. The increasing pressure to use non-hazardous, environmentally compatible pest control measures have spurred interest in the use of natural insecticides such as Bacillus thuringiensis $B t$ insecticidal crystal proteins in a number of countries [6,7]. Development of insect resistant sorghum by transferring $\mathrm{Bt}$ genes is one of the best ways available today to overcome insect attack and to improve the yield of sorghum. There are many reports on successful transformation of sorghum utilizing particle bombardment $[\mathbf{8 , 1 1}$ or Agrobacterium mediated transformation $[12,13]$. But till date there is only one report available on sorghum transformation employing particle bombardment with Cry1AC gene [14]. A moderate level of tolerance was reported, which in turn conferred partial protection against neonate larvae of the spotted stem borer (Chilo partellus).

Cry $1 C$ toxin is effective against a wide variety of lepidopteran insect pests including stem borers and leaf folders and does not share a common binding site with Cry1A toxins [15-18]. Sakai et al., [19] studied the role of protein domain of $\mathrm{Cry} 1 \mathrm{C}$ protein that confers its specificity to Spodoptera sp. by domain swapping studies on the protein and then analyzing the cytotoxicity to Sf9 insect cell lines. Transgenic crops such as alfalfa and tobacco expressed a modified $\mathrm{Cry} 1 \mathrm{Ca}$ gene and the transgenic plants 
Ignacimuthu et al. Molecular Biology and Genetic Engineering 2014,

showed enhanced resistance to Egyptian cotton leafworm (Spodoptera littoralis) and the beet armyworm. Broccoli plants were transformed with a modified Cry $1 \mathrm{C}$ gene [20] and the transgenic plants showed high insect resistance to diamond backboth (Plutella xylostella). Synthetic Cry1C genes were found to be highly resistant to stem borers and leaf folders [21]. Cry $1 C$ toxins can be potential alternative to $C r y 1 A C$ and Cry $1 A$ toxins and can also be combined with other Cry $1 A C$ and Cry $1 \mathrm{~A}$ genes. Therefore, it would appear that the Cry $1 C$ toxin can be a potential alternative to $C r y 1 A$ toxins and that it can also be combined with other Cry $1 A$ genes to develop $B t$ crops with two-toxin $[22,23]$.

In the present study we employed Agrobacterium-mediated transformation using Cry $1 \mathrm{C}$ to confer resistance to Chilo partellus. The plant expression vector containing the reporter gene uidA (GUS), the selectable marker gene hpt and the Cry1C gene under the control of CAMV35S promoter was introduced via Agrobacterium-mediated transformation of selected sorghum genotype. Insect bioassay of the transformed plants was carried out to assess the level of resistance to Chilo partellus.

\section{Materials and methods}

\section{Plant material and tissue culture}

Cultivars of sorghum (Sorghum bicolor (L.) Moench) variety APK I was used for tissue culture and transformation studies. The seeds were obtained from the germplasm bank of Tamil Nadu Agriculture University, Coimbatore, for experimental use. This variety is being cultivated in many states of India. Seeds were washed in running tap water several times. After washing they were treated with Tween 20 detergent solution (Qualigens, Mumbai, India) for 5 minutes and rinsed in double distilled water. The rest of the sterilization process of seeds was carried out inside the laminar airflow hood. Seeds were surface-sterilized with $70 \%$ ethanol $(\mathrm{v} / \mathrm{v})$ for 30 seconds followed by treatment with $0.1 \%(\mathrm{w} / \mathrm{v})$ mercuric chloride $\left(\mathrm{HgCl}_{2}\right)$ for 6 minutes and were washed six times with sterile double distilled water to remove the sterilant and used for further studies. Seeds were germinated on MS basal medium containing sucrose. The $\mathrm{pH}$ of the medium was adjusted to appropriate $\mathrm{pH} 5.6$ to 5.8 using $1 \mathrm{~N} \mathrm{KOH}$ or $1 \mathrm{~N} \mathrm{HCl}$ solutions prior to adding agar; media were autoclaved at $121^{\circ} \mathrm{C}$ for 15 minutes. Cultures were maintained at $24 \pm 2^{\circ} \mathrm{C}$ under cool white fluorescent tubes of (90-150 $\mu \mathrm{mol}$ photons $\left.\mathrm{m}^{-2} \mathrm{~s}^{-1}\right)$ light intensity.

Agrobacterium tumefaciens strains, plasmid and culture Codon optimised Cry $1 \mathrm{C}$ gene cassette (kindly provided by Dr. I. Altosaar) for expression in plants (double 35s promoter+AMV enhancer-Cry $1 \mathrm{C}$-nos terminator) was inserted into the multiple cloning site of pCAMBIA1305.1 resulting in the formation of a plasmid pCAMBIA1305.1/Cry1C (Figure 1). The plasmid was introduced into the disarmed Agrobacterium strain LBA 4404 by freeze thaw method [24] and confirmed by plasmid

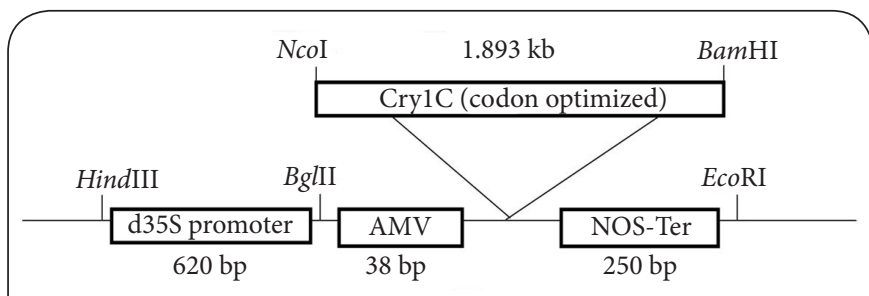

Figure 1. Vector map showing the Cry1C construct cloned in pCAMBIA 1305.1.

rescue and restriction analysis. Liquid YEP (10 g/L peptone, $5 \mathrm{~g} / \mathrm{L} \mathrm{NaCl}, 10 \mathrm{~g} / \mathrm{L}$ yeast extract and $\mathrm{pH}$ 7) medium $(50 \mathrm{ml})$ containing kanamycin $(50 \mathrm{mg} / \mathrm{l})$ and $10 \mathrm{mg} / \mathrm{l}$ of rifamycin was inoculated with a single colony of Agrobacterium and shaken at $28^{\circ} \mathrm{C}$ in an incubator at $175 \mathrm{rpm}$ until the $\mathrm{OD}_{600}$ reached to 0.8 . At this time, $15 \%$ glycerol stocks were made and stored at $-70^{\circ} \mathrm{C}$. The day before Agrobacterium transformation, $100 \mu \mathrm{l}$ of A. tumefaciens glycerol stock was added to $30 \mathrm{ml} \mathrm{YEP} \mathrm{medium}$ with kanamycin $(50 \mathrm{mg} / \mathrm{l})$ and shaken at $28^{\circ} \mathrm{C}$ for 16 hour at 175 rpm on a rotary shaker incubator (Orbitek, India) until the $\mathrm{OD}_{600}$ reached to about 0.6-1.0. Before inoculation, the culture was centrifuged for $10 \mathrm{~min}$ at $6,000 \mathrm{rpm}$ at $20^{\circ} \mathrm{C}$ to pellet the cells. The resulting pellet was dissolved in 10 to $15 \mathrm{ml}$ (depending on the pellet size) of liquid pre-induction medium [AA medium [25], 20gm/l sucrose, 200 $\mu \mathrm{M}$ acetosyringone, $\mathrm{pH} 5.5$ (AA-AS)] and incubated at $28^{\circ} \mathrm{C}$ for $15 \mathrm{~min}$ for transformation studies.

\section{Cocultivation, selection and plant regeneration}

Shoot tip explants excised from 3-5days old seedlings were soaked in $15 \mathrm{ml}$ of LBA 4404 bearing pCAMBIA1305.1/Cry1C for $30 \mathrm{~min}$; after that they were blotted dry with sterile filter paper to remove excess bacteria. Cocultivation was done for $72 \mathrm{hr}$. For each experiment approximately 100 explants were used. Then they were cultured in coculture medium [(MS major salts, MS minor salts, MS vitamins, $300 \mathrm{mg} / \mathrm{l}$ casein acid hydrolysate, $500 \mathrm{mg} / \mathrm{l}$ L-proline, $2.5 \mathrm{mg} / \mathrm{l}$ 2,4-D, $0.25 \mathrm{mg} / \mathrm{l}$ kinetin, $30 \mathrm{~g} / \mathrm{l}$ sucrose, $7 \mathrm{~g} / \mathrm{l}$ agar, $\mathrm{pH}$ 5.5, $200 \mu \mathrm{M}$ acetosyringone (CIM-AS)]. The plates were sealed with parafilm. Cocultivation was carried out in the dark at $25^{\circ} \mathrm{C}$ for 3 days. The calli labelled as control were not infected with Agrobacterium. After cocultivation, the infected calli were washed $3-5$ times with sterilized deionized water containing $500 \mathrm{mg} / \mathrm{l}$ cefotaxime to kill Agrobacterium. The inoculated calli were first transferred to callus induction medium [MS major salts, MS minor salts, MS vitamins, 300 $\mathrm{mg} / \mathrm{l}$ casein acid hydrolysate, $500 \mathrm{mg} / \mathrm{l} \mathrm{L}$-proline, $2.5 \mathrm{mg} / \mathrm{l}$ 2,4-D, $0.25 \mathrm{mg} / \mathrm{l} \mathrm{kinetin,} \mathrm{30g/l} \mathrm{sucrose,} 7 \mathrm{~g} / \mathrm{l}$ agar, pH 5.7 (CIM)] containing $500 \mathrm{mg} / \mathrm{l}$ cefotaxime for 1 week of callus growth without selection and then transferred to selection medium [(MS major salts, MS minor salts, MS vitamins, $300 \mathrm{mg} / \mathrm{l}$ casein acid hydrolysate, $500 \mathrm{mg} / \mathrm{l} \mathrm{L-proline,} 2.5 \mathrm{mg} / \mathrm{l}$ 2,4-D, $30 \mathrm{~g} / \mathrm{l}$ sucrose, $7 \mathrm{~g} / \mathrm{l}$ agar, $\mathrm{pH} 5.7$, plus $5 \mathrm{mg} / \mathrm{l}$ hygromycin and 500 $\mathrm{mg} / \mathrm{l}$ cefotaxime $(\mathrm{CIM}-\mathrm{CCH})]$. After three rounds of selection, each $2-3$ weeks, resistant calli were transferred to regeneration 
medium [MS major salts, MS minor salts, MS vitamins, $300 \mathrm{mg} / \mathrm{l}$ casein acidhydrolysate, $500 \mathrm{mg} / \mathrm{l}$, L-proline, $30 \mathrm{~g} / \mathrm{l}$ sucrose, $4 \mathrm{mg} / \mathrm{l} \mathrm{BAP}$ and $7 \mathrm{~g} / \mathrm{l}$ agar, $\mathrm{pH} 5.7$ plus $250 \mathrm{mg} / \mathrm{l}$ cefotaxime and $5 \mathrm{mg} / \mathrm{l}$ hygromycin (RE2-CCH)] for shoot development. The regenerated shoots were further transferred to RE2-CCH medium for full plantlet formation and then rooted on MS medium. After rooting, the transgenic plants were transferred to a glasshouse and grown to maturity. Three different experiments were done.

\section{GUS histochemical assay}

The histochemical assay for GUS gene expression ( $\beta$-DGlucuronidase) was performed in sorghum shoot tip calli with 5-Bromo-4-Chloro-3-Indolyl Glucuronide (X-Gluc) as a substrate by established methods [26,27]. Following cocultivation, tissues were harvested for GUS staining. The putative transgenic sorghum explants were incubated in Sodium Phosphate buffer $\left(50 \mathrm{mM} \mathrm{NaPO}_{4^{\prime}} \mathrm{pH} 6.8\right.$ ) that contained $1 \%$ Triton $\mathrm{X}-100$ at $37^{\circ} \mathrm{C}$ for 1 hour. The putative transgenic explants were incubated overnight in a solution containing $1.0 \mathrm{mM}$ $X$-Gluc, $10 \mathrm{mM}$ EDTA, $100 \mathrm{mM} \mathrm{NaH}_{2} \mathrm{PO}_{4^{\prime}} 0.1 \mathrm{x}$ Triton X-100 and $20 \%$ methanol ( $\mathrm{pH}$ 5.8). The reaction mixture was incubated overnight at $37^{\circ} \mathrm{C}$ and the number of tissues that stained blue was counted. To suppress endogenous b-glucuronidase activity, we added $20 \%$ methanol to the reaction buffer. The tissue was washed twice in $99 \%$ methanol for two hours to remove the chlorophyll pigment.

\section{PCR analysis of putative transgenic plants}

PCR analysis was carried out using the following primers 5 primer, 5'-CCA TGG AGG AGA ACA ATC AGA ACC AGT G-3'; 3' primer, 5'-GGA TCC TAC TTT TGT GCT CTT TCA AGG TC-3'. These primers amplified a $1.9 \mathrm{~kb}$ fragment from the $C r y 1 C$ gene respectively. PCR analysis was carried out in a reaction volume of $25 \mu \mathrm{l}$ containing the template genomic DNA (100 $\mathrm{ng}), 2.5 \mu \mathrm{l} 10 \mathrm{X}$ PCR amplification buffer, $0.5 \mu \mathrm{l} 10 \mathrm{mM}$ dNTPS, $1.2 \mu \mathrm{l} 50 \mathrm{mM} \mathrm{MgCl} 2,3 \mu \mathrm{M}(2.5 \mu \mathrm{l})$ of each primer, $13.6 \mu \mathrm{l}$ sterile distilled water, 1 unit $(0.20 \mu \mathrm{l}$ of Taq DNA polymerase (Genei). The samples were heated to $94^{\circ} \mathrm{C}$ for $5 \mathrm{~min}$ and then subjected to 30 cycles of $30 \mathrm{~s}$ melting at $94^{\circ} \mathrm{C}, 30 \mathrm{~s}$ annealing at $60^{\circ} \mathrm{C}$ and $1 \mathrm{~min}$ synthesis at $72^{\circ} \mathrm{C}$ and followed by another $10 \mathrm{~min}$ final extension at $72^{\circ} \mathrm{C}$. The amplified products were assayed by electrophoresis on $0.8 \%$ agarose gels, stained with ethidium bromide (EtBr; $0.5 \mathrm{mg} / \mathrm{ml})$, visualized and photographed under ultraviolet light.

\section{Southern hybridization}

The $S_{1}$ transformants were subjected to Southern blot hybridization analysis using the coding sequence of $\mathrm{Cry} 1 \mathrm{C}$ gene. Southern blot analysis was done using genomic DNA of putative $\left(\mathrm{S}_{1}\right)$ transformants positive to $\mathrm{PCR}$ and untransformed control plants. DNA was digested with HindIII and EcoRl; the blot analysis was carried out using ten microgram of genomic DNA. The digested DNA was resolved on $0.8 \%$ agarose gels. DNA was transferred to negatively charged nylon membrane (as per the manufactures instructions) for Southern hybridization analysis [28]. The coding sequences of Cry1C genes were labelled with biotin-11-dUTP using Biotin Decalabel DNA Labelling Kits (Fermentas Life sciences) and used as a probe. The blot was subjected to detection by overnight colour development using biotin chromogenic detection kit (Fermentas Life sciences).

\section{Bioassay of transgenic sorghum}

Chilo partellus (Swinhoe) egg masses were obtained from International Crop Research Institute for Semi Arid Tropics (ICRISAT) and maintained in Entomology Research Institute (ERI). The standardized artificial diet composition for spotted stem borer (C. partellus) contained chickpea flour (219.2g), sorghum leaf powder (80g), sorbic acid (2g) methyl p-hydroxy benzoate $(4.2 \mathrm{~g})$, ascorbic acid $(5.2 \mathrm{~g})$, yeast $(16 \mathrm{~g})$, water $(1000 \mathrm{ml})$, agar-agar (20.4g), water for agar ( $800 \mathrm{ml})$, formaldehyde $10 \%$ $(2.5 \mathrm{ml})$ and vitamin $\mathrm{E}(400 \mathrm{mg})$. Young shoots from 35 days old transformed and untransformed sorghum plants were washed in distilled water and the excess water was removed from the shoots using tissue paper. Five sorghum shoots of 5 $\mathrm{cm}$ sections were placed in petri dishes with moist filter paper. The larvae were starved for 4-3 hours before introducing them into the petri dishes. Five freshly hatched $2^{\text {nd }}$ instar larvae of stem borer were introduced into petri-plates containing the sorghum shoots. The petri dishes were maintained at the insectary in ERI $\left(28 \pm 1^{\circ} \mathrm{C} / 70 \%\right.$ R.H). After $72 \mathrm{hr}$ insect death was recorded. Percentage of shoot weight damage was calculated by measuring the total shoot weight before and after bioassay. Each experiment was replicated five times.

\section{Results \\ Transformation and regeneration of transformed sorghum plants}

The Cry1C gene was introduced into shoot apices derived from 3-4 days old seedling explants of the APK 1 cultivar by Agrobacterium-mediated gene transfer method (Figure 2A). The shoot apices cocultivated with LBA4404 (pCAMBIA1305.1/ Cry 1C) produced hygromycin resistant calli (Figure 2B) after 42 days of co-cultivation in the selection medium (CIM-CCH) containing $5 \mathrm{mg} / \mathrm{l}$ hygromycin, $250 \mathrm{mg} / \mathrm{l}$ carbencillin and $500 \mathrm{mg} / \mathrm{l}$ cefotaxime. After 42 days of selection, the hygromycin resistant calli were removed and subcultured in a fresh selection medium. Growth of the calli, which were not infected with Agrobacterium, was effectively inhibited in a medium containing $5 \mathrm{mg} / \mathrm{l}$ hygromycin (Negative control). The positive control shoot apex (not infected with Agrobacterium) efficiently proliferated in the callus induction medium in the absence of hygromycin. A high frequency of hygromycin resistant calli was observed in three different experiments (Table 1). Out of 237 $(76+79+82)$ shoot apex calli cocultivated in three experiments $99(34+36+29)$ hygromycin resistant calli were obtained to an overall percentage of 41.7 . In the present study, mature 
Ignacimuthu et al. Molecular Biology and Genetic Engineering 2014,

Table 1. Summary of genetic transformation of APK 1 sorghum shoot apex calli explants by Agrobacterium tumefaciens LBA4404 (pCAMBIA1305.1/Cry1C).

\begin{tabular}{l|llllll}
\hline Sorghum cultivar & \multicolumn{6}{l}{ Number of shoot apex calli LBA4404 (pCAMBIA1305.1/Cry1C) } \\
\cline { 2 - 7 } & $\begin{array}{l}\text { Experiment } \\
\text { Number }\end{array}$ & Cocultivated (A) & Produced HyR calli & $\begin{array}{l}\text { Produced } \\
\text { HyR plants }\end{array}$ & $\begin{array}{l}\text { Produced HyR and GUS+ plants } \\
(B)\end{array}$ & $\begin{array}{l}\text { Trans formation } \\
\text { efficiency (\%) (B/A) }\end{array}$ \\
\hline APK 1 & 1 & 76 & 34 & 26 & 3 & 3.9 \\
& 2 & 79 & 36 & 28 & 1 & 1.2 \\
& 3 & 82 & 29 & 22 & 2 & 2.4 \\
\hline
\end{tabular}

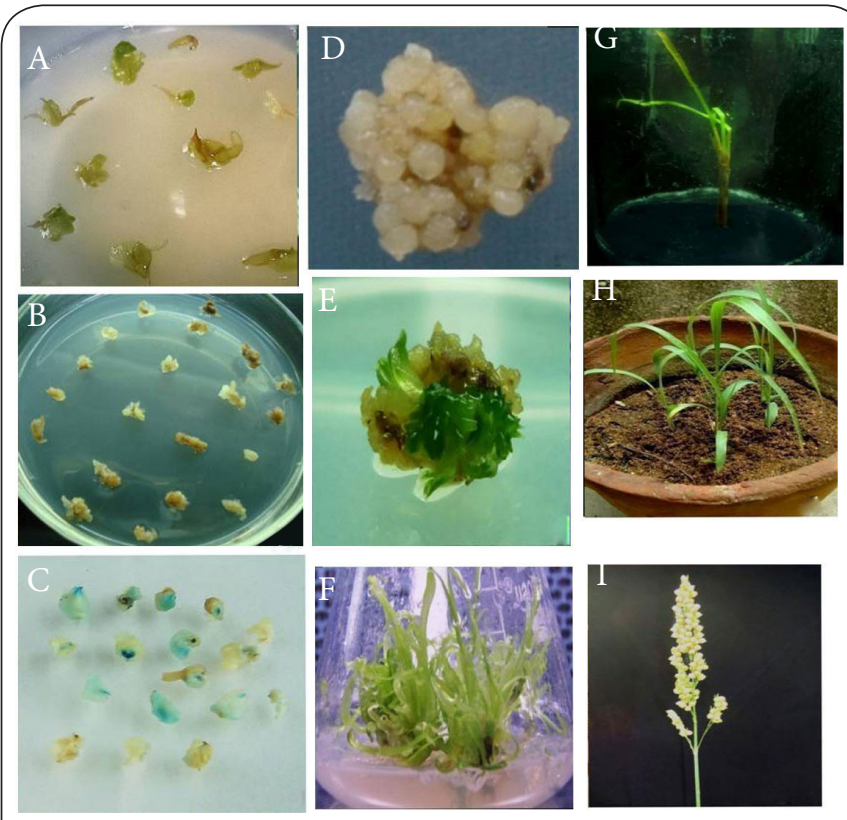

Figure 2. Transformation and regeneration of transformed sorghum plants and GUS Histochemical assay.

(A). Shoot apex explants of sorghum cultivar APK 1 (Sorghum bicolor L. cv. APK1) after infection with Agrobacterium tumefaciens LBA4404 (pCAMBIA1305.1/Cry1C). (B).

Hygromycin resistant calli of the sorghum cultivar (Sorghum bicolor L. cV. APK1) after 42 days of cocultivation in selection medium. (C). The transient expression of GUS gene in the calli of sorghum cultivar APK 1 (Sorghum bicolor L. cv. APK1) after cocultivation with Agrobacterium tumefaciens LBA4404 (pCAMBIA1305.1) for ten days. (D). Hygromycin resistant embryogenic calli of sorghum (Sorghum bicolor L. cv. APK1) on regeneration medium. (E). The proliferation of hygromycin resistant shoots of the sorghum (Sorghum bicolor L. cv. APK1) after further subculture to selection medium. (F). Proliferation of hygromycin resistant plants of the sorghum cultivar (Sorghum bicolor L. cv. APK1) after further subculture on regeneration medium. (G). Rooting of hygromycin resistant plants of the sorghum cultivar (Sorghum bicolor L. cv. APK1) on rooting medium. $(\mathbf{H})$. Transformed sorghum (Sorghum bicolor L. cv. APK1) plants at in vivo conditions. (I). Panicle of transformed sorghum (Sorghum bicolor L. cv. APK1) plants.

seedling derived shoot apices of APK I cultivars were used as explants for Agrobacterium mediated genetic transformation.

\section{GUS Histochemical assay}

Most of the hygromycin resistant calli that survived on the selection medium produced intense blue colour after overnight incubation with X-gluc substrate solution (Figure $\mathbf{2 C}$ ). The hygromycin resistant and GUS positive embryogenic calli (Figure 2D) were transferred to regeneration medium containing $3 \mathrm{mg} / \mathrm{l}$ hygromycin, $250 \mathrm{mg} / \mathrm{l}$ cefotaxime (RE2-CCH). Small shoots were observed on the transformed calli after three weeks of growth (Figure $\mathbf{2 E}$ ) and the regenerating calli were subcultured in a fresh regeneration medium and maintained for another three weeks. In three independent experiments, a total of 71 hygromycin resistant plants were regenerated from 99 calli (Figure 2F). After 6 weeks on the regeneration medium, the plantlets were rooted (Figure $\mathbf{2 G}$ ) on the rooting medium (RIM-CCH). Small leaf pieces from the putatively transformed shoots were used for GUS histochemical assay. In these assays, 47 of the 76 regenerated shoots showed blue precipitate. These plantlets were hardened (Figure $\mathbf{2 H}$ ) and transferred to field condition and set seeds (Figure 2I). This cultivar APK I showed a transformation frequency ranging from 1.2\%-3.9\% (Table 1).

\section{PCR analysis of hygromycin resistant transgenic sorghum plants}

Total DNA from three APK I putative transformants, resulting from infection with LBA4404 (pCAMBIA1305.1/Cry1C) were subjected to PCR analysis with Cry $1 \mathrm{C}$ genes primers. PCR was performed to confirm the presence of the Cry $1 \mathrm{C}$ gene. All the three putative transformants were found to be positive for the amplification of $1.9 \mathrm{~kb}$ (Figure 3) Cry $1 \mathrm{C}$ gene. A similar band was also observed in the positive plasmid control, while no such band was noticed in the untransformed control. This indicated that the tissues were completely cured of Agrobacterium.

\section{Southern analysis of transgenic sorghum plants}

Southern hybridization analysis was performed to confirm T-DNA integration (Figure 4). The transformants $\left(\mathrm{S}_{1}\right)$ of the cultivar APK I were subjected to genomic southern hybridization. Genomic DNA samples $(10 \mu \mathrm{g})$ from control and four $S_{1}$ transgenic plants were subjected to southern analysis. The coding sequences of Cry $1 \mathrm{C}$ were used as probes for T-DNA integration (pCAMBIA1305.1/Cry1C).

Genomic DNA $(10 \mu \mathrm{g})$ from GUS and PCR positive sorghum 


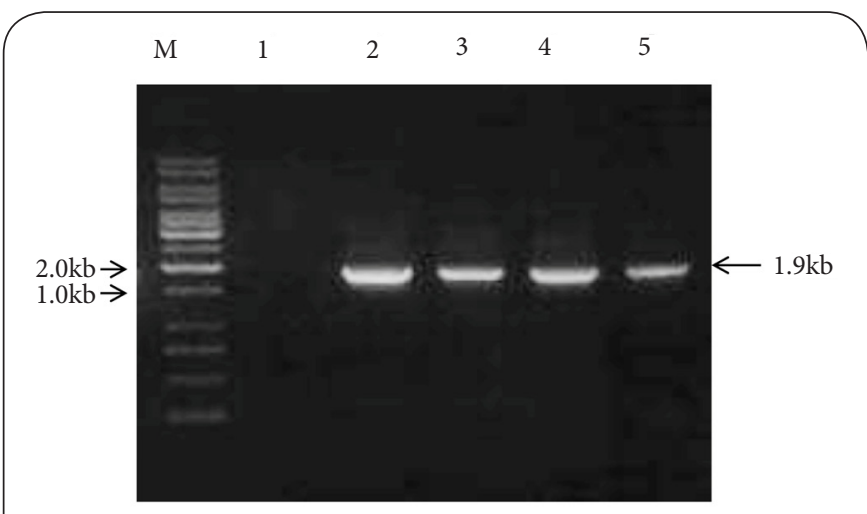

Figure 3. PCR analysis of genomic DNA, isolated from putative transgenic sorghum (Sorghum bicolor $\mathrm{L}$. cv. APK1) plants resulting from infection with LBA4404 (pCAMBIA1305.1/Cry1C plasmid).

Each lane represents an individual plant. Lane M, $1 \mathrm{~kb}$ Marker. Lane 1, DNA from untransformed control. Lane 2, Plasmid DNA positive control. Lane 3, transformed plant (APK 1- Bt-1). Lane 4, transformed plant (APK 1-Bt-2). Lane 5 transformed plant (APK 1- Bt-3).

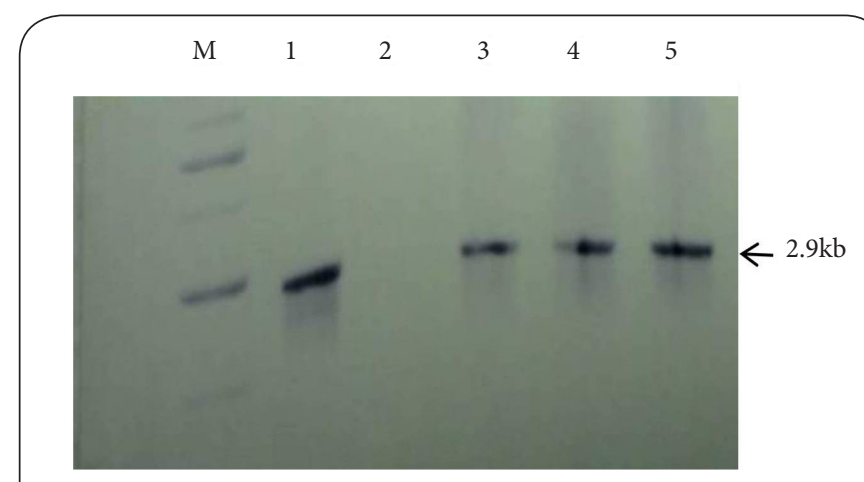

Figure 4. Southern analysis of four transgenic plants of APK 1 cultivar (Lanes 3-6) and an untransformed plant using biotin labelled method.

A 2.9kb biotin labelled Cry $1 C$ fragment was used to probe genomic DNA isolated from leaves of transgenic and non transgenic lines. Genomic DNA was digested with HindIII restriction enzyme, fractionized by electrophoresis, transferred to nylon membrane, and allowed to hybridize with $\mathrm{Cry} 1 \mathrm{C}$ gene along with the promoter, double 35S CaMV promoter plus AMV enhancer (HindIII and EcoRI fragment of pCAMBIA1305.1/Cry1C plasmid). Lane M, Biotin labelled molecular marker. Lane 1, pCAMBIA 1305.1/Cry 1C plasmid double digested with HindIII and EcoRI as positive control. Lane 2, DNA from untransformed plant as a negative control. Lane 3, transformed plant (APK 1-Bt-1). Lane 4, transformed plant (APK 1-Bt-2). Lane 5, transformed plant (APK 1-Bt-3). Lane 6, transformed plant (APK 1-Bt-4).

plants was digested with HindIII and EcoRl enzymes, which would release an internal fragment size $2.9 \mathrm{~kb}$ Cry $1 \mathrm{C}$ gene along with d35S promoter. The Cry $1 \mathrm{C}$ gene sequence was detected as a fragment size $(2.9 \mathrm{~kb})$ in transformed plants (Figure 4). Since Cry1C probe hybridized to genomic DNA from transgenic plants but not to DNA from non-transformed control plants, the result indicated that Cry 1 C DNA was incorporated into sorghum genome and Southern blot analysis of transformants confirmed integration of $2.9 \mathrm{~kb} \mathrm{Cry} 1 \mathrm{C}$ coding sequences into the sorghum genome.

\section{Segregation analysis of the transgene in sorghum}

A segregation analysis was performed to check the pattern of transgene segregation in $S_{1}$ progenies of sorghum plants transformed with selectable marker and reporter genes. The transgenic lines of APK I variety were screened on hygromycin ( $5 \mathrm{mg} / \mathrm{l}$ ) supplemented medium to test the resistance and susceptibility of $S_{1}$ seeds. Data were validated by Chi-square $\left(X^{2}\right)$ analysis (Table 2). The transgenic lines (APK I) gave the $\mathrm{S}$, segregation of $\mathrm{Hyg}^{R} / \mathrm{Hyg}^{S}$ in the ratio of 3:1 confirming the normal Mendelian pattern of segregation. This study confirmed the successful introduction, integration and normal $\mathrm{S}_{1}$ segregation of transgene in sorghum.

\section{Bioassay of transgenic sorghum}

$\mathrm{S}_{1}$ transgenic plants expressing $\mathrm{Cry} 1 \mathrm{C}$ were infested with sorghum stem borer larvae. The results are summarized in (Table 3). All the three transgenic lines showed high level of insect mortality. Feeding damage was estimated to be only $5 \%$ on transgenic plants. On control plants there was no mortality and $100 \%$ of the edible portion of the leaf material was consumed over a period of 3 days. In experiments using transformants expressing a single $B t$ toxin, $97-100 \%$ mortality was observed, with 10-13\% leaf damage. Conversely, larvae feeding on control plants developed normally, causing massive tissue damage during the bioassay period.

\section{Discussion}

Sorghum is considered to be one of the most difficult plant species to manipulate through tissue culture and transformation. The first reports of sorghum plants transformed with agronomically important genes were the use of the HT12 gene for higher grain lysine content [29] employing Agrobacterium and the Cry1 ACgene for insect resistance [14] employing particle bombardment. Although sorghum tissue culture, including callus induction and plant regeneration, has been successful [13,30-38], genetic transformation of sorghum for commercial use was much less successful because of the lack of effective protocols [36]. Although work on transformation of sorghum began during 1990s, much less success has been achieved than with other crops. The first report of genetic transformation of sorghum described the introduction of DNA into protoplasts by electroporation and selection of transformed cells, without achieving plant regeneration [39].

Casas et al., [40] obtained the first transgenic sorghum plants with bombardment of immature embryos and later on they obtained transgenic plants using immature inflorescences. Casas et al., [40] and Zhu et al., [41] reported success in sorghum 
Ignacimuthu et al. Molecular Biology and Genetic Engineering 2014,

http://www.hoajonline.com/journals/pdf/2053-5767-2-1.pdf

doi: $10.7243 / 2053-5767-2-1$

Table 2. Segregation of hygromycin resistant gene and GUS gene in S1 generation of sorghum plants transformed with Agrobacterium tumefaciens LBA4404 (pCAMBIA 1305.1/Cry1C).

\begin{tabular}{|c|c|c|c|c|c|c|c|c|c|}
\hline \multirow[t]{2}{*}{ Transformants Number } & \multirow{2}{*}{ Total $S_{1}$ seeds tested } & \multicolumn{4}{|c|}{ Hygromycin } & \multicolumn{4}{|l|}{ GUS } \\
\hline & & Resistant & Sensitive & Ratio & $\mathrm{X}^{2}$ value & Positive & Negative & Ratio & $\mathrm{X}^{2}$ value \\
\hline APK 1-Bt-5 & 47 & 38 & 11 & 3:1 & 0.7 & 40 & 12 & $3: 1$ & 0.7 \\
\hline APK 1-Bt-7 & 33 & 19 & 7 & $3: 1$ & 1.15 & 17 & 9 & $3: 1$ & 1.15 \\
\hline APK 1-Bt-9 & 26 & 17 & 5 & $3: 1$ & 0.52 & 23 & 7 & $3: 1$ & 0.52 \\
\hline
\end{tabular}

Table 3 Percent insecticidal and shoot damage on transformed and untransformed plants expressing the Cry1C gene against spotted stem borer (Chilo partellus) after 72 hrs feeding.

\begin{tabular}{lll}
\hline Plant lines & \% shoot damage & \% insecticidal \\
\hline APK 1 (untransformed) & 99.22 & - \\
APK 1-Bt-1 & 4.56 & 100 \\
APK 1-Bt-2 & 2.73 & 97.7 \\
APK 1-Bt-3 & 5.38 & 93.3 \\
\hline
\end{tabular}

transformation with biolistic bombardment. However, the disadvantages of using biolistic bombardment are that it produces multiple copies [14] of the transgene that may lead to silencing with usually low transformation efficiency. Godwin et al., [42] reported inoculation of sorghum meristem tissue with Agrobacterium. Zhao's research group [12] was the first to report the successful Agrobacterium-mediated genetic transformation of sorghum and the production of transgenic plants that transmitted the introduced gene to progeny in a Mendelian fashion. Much of the work on sorghum transformation by earlier investigators focussed on the optimization of parameters for tissue culture and gene transfer methods, assessing the strength of promoters, and identification of efficient selectable marker and reporter genes $[8,43]$. Only a few reports dealt with transformation of sorghum with an agronomically important gene, rice chitinase, that confers resistance against stalk rot [41] and spotted stem borer (Chilo partellus) [14].

Shoot apices are used as explants in many cereals since they produce plantlets identical to their parents. Main steps involved in shoot apex culture are the separation of tissues surrounding the meristem followed by exposing the meristem by creating wounds [44]. Girijashankar et al., [14] used shoot apices of sorghum BTX623 genotype for cotransformation with a selectable marker (bar) and an insect resistant (Cry1AC) gene using plasmids pJS108 and pmpiClcry1AC. Our study demonstrated that the transfer of foreign genes to sorghum via Agrobacterium tumefaciens LBA4404 (pCAMBIA1305.1) by the shoot apex was efficient. Aragao et al., [45] transformed bean plants with a chimeric construct containing the doubled $35 \mathrm{~S}$ CaMV promoter plus the AMV enhancer sequence, assuming that its performance would be superior to the native $35 \mathrm{~S}$ promoter. In the present study, a large number of sorghum plants carrying Cry $1 \mathrm{C}$ gene has been produced in APK 1 cultivar by Agrobacterium mediated transformation method using

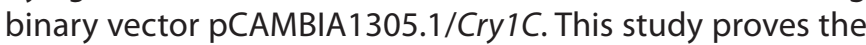
efficiency and effectiveness of the Agrobacterium tumefaciens LBA4404 (pCAMBIA1305.1/Cry1C) in transforming the sorghum plants. In genetic transformation of crops one of the most widely used selection markers is the gene encoding hygromycin phosphotransferase (hpt). These marker genes along with the constitutive promoters such as CaMV35S work efficiently for the selection of transformed cells. The hpt gene has been used as an efficient tool for selection of transformed calli [46-48]. We used hygromycin as a selection marker at 5 $\mathrm{mg} / \mathrm{L}$. This was very effective for selection. $h p t$ gene has been reported to be more efficient and an acceptable marker for sorghum transformation [48].

One of the main objectives of the present study was to express the $\mathrm{Cry} 1 \mathrm{C}$ gene in transgenic sorghum plants to provide resistance to the stem borer (Chilo partellus). The transgene's coding sequence was driven by a doubled $35 \mathrm{~S}$ CaMV promoter and AMV enhancer sequences, which would direct and ensure the expression of recombinant protein in the whole plant. PCR amplification confirmed the presence of Cry $1 \mathrm{C}$ gene in transformed sorghum plants which generated $1.9 \mathrm{~kb}(\mathrm{Cry} 1 \mathrm{C})$ genes equal to the size of the positive control and there was no amplification in the non-transformed control plants. Successful integration of Cry1C gene into sorghum was further confirmed by performing a Southern blot with genomic DNA (Hind III and EcoRI digest) of PCR positive plants. All $P C R$ positive plants produced signals at $2.9 \mathrm{~kb}$ which is the expected band size of $\mathrm{Cry} 1 \mathrm{C}$ expression cassette indicating the integration of the $\mathrm{Cry} 1 \mathrm{C}$ gene into the genome of sorghum and proved that they are derived from independent transformants. Southern hybridization analysis offers many advantages in the analysis of transgenic plants [49] and is equally informative as real-time PCR analysis [50]. Segregation of the Cry $1 \mathrm{C}$ gene in the next generation was examined by hygromycin resistance and GUS assay experiments. Segregation analysis of these three independent $\mathrm{S}$ lines demonstrated that the transgenes were stably inherited in $\mathrm{S}_{2}$ progeny. The transformation efficiency in our study was found to be ranging between 1.2\%-3.9\%; only $1.5 \%$ was reported by [14].

Chilo partellus Swinhoe (Lepidoptera: Pyralidae) which is an important pest of sorghum is found in India [51] and South and eastern Africa [52]. Brietler et al., [53] reported that transgenic 
rice plants carrying $\mathrm{Cry} 1 \mathrm{~B}$ under control of the $\mathrm{mpiC} 1$ promoter expressed the $\delta$-endotoxin to levels of up to $0.2 \%$ of total soluble protein, and these plants exhibited $100 \%$ resistance to second-instar larvae of striped stem borer (Chilo suppressalis Walker). Datta et al., [54] reported that, in transgenic rice plants, 10-200 ng Cry $1 A b$ protein per gram of leaf tissue was capable of conferring $100 \%$ larval mortality on the yellow stem borer in cut-stem bioassays. The results of our bioassay study revealed significant larval mortality and reduction in tissue damage by the stem borer larvae in transformed plants, where as larvae feeding on control plants developed normally, and caused massive tissue damage during the bioassay period, which indirectly indicated the presence of the Cry $1 \mathrm{C}$ gene. Bioassay studies proved the expression pattern of $\mathrm{Cry} 1 \mathrm{C}$ gene in all four transgenic lines, which also revealed $\mathrm{Cry} 1 \mathrm{C}$ protein activity. The insect mortality observed in the present study was coinciding with the previous studies $[14,55,56]$. Our study clearly established that transgenic plants which were resistant to Chilo partellus were produced with stable integration of Cry1C gene with high larval mortality.

\section{Competing interests}

The authors declare that they have no competing interests.

\section{Authors' contributions}

\begin{tabular}{|l|c|c|}
\hline Authors' contributions & SI & AP \\
\hline Research concept and design & $\checkmark$ & $\checkmark$ \\
\hline Collection and/or assembly of data & $\checkmark$ & $\checkmark$ \\
\hline Data analysis and interpretation & $\checkmark$ & $\checkmark$ \\
\hline Writing the article & $\checkmark$ & $\checkmark$ \\
\hline Critical revision of the article & $\checkmark$ & $\checkmark$ \\
\hline Final approval of article & $\checkmark$ & $\checkmark$ \\
\hline Statistical analysis & $\checkmark$ & $\checkmark$ \\
\hline
\end{tabular}

\section{Acknowledgement}

We thank the visiting professorship program, deanship of scientific research at King Saud University, Riyadh. We would like to thank Dr. I. Altosaar, Ottawa University, Canada, for kindly providing us the Cry1C genes. We would like to thank Dr K. Vanagamudi, Seed Science and Technology Division, TNAU, for kindly providing us the sorghum APK1 seeds. We would also like to thank Dr S. Raveendar, Entomology Research Institute for his help during the work.

\section{Publication history}

Editor: Liping Gu, South Dakota State University, USA.

EIC: Kenneth Maiese, Wayne State University, USA.

Received: 01-Oct-2013 Revised: 11-Nov-2013

Re-Revised: 21-Jan-2014 Accepted: 28-Feb-2014

Published: 21-Mar-2014

\section{References}

1. Paterson AH, Bowers JE, Peterson DG, Estill JC and Chapman BA. Structure and evolution of cereal genomes. Curr Opin Genet Dev. 2003; 13:644-50. | Article | PubMed

2. Deu M, Gonzalez-de-Leon D, Glaszmann JC, Degremont I, Chantereau J, Lanaud $C$ and Hamon P. RFLP diversity in cultivated sorghum in relation to racial differentiation. Theor Appl Genet. 1994; 88:838-44. | Article |
PubMed

3. BSTID-NRC [Board on Science and Technology for International Development- National Research Council]. Lost crops of Africa. Academic Press, Washington DC. 1996; 127-213.

4. Vimala V, Kaur KJ and Hymavati TV. Processing of millets-scope for diversification. Proceedings of the Summer Institute on Appropriate Food Processing Technologies for Rural Development. 15 June - 4 July, Andhra Pradesh Agricultural University, Hyderabad, India. 1990; 39523952.

5. Subramanian $V$ and Jambunathan R. Traditional methods of processing of sorghum (Sorghum bicolour) and pearl millet (Pennisetum americanum) grains in India. Report of the Int Assoc Cereal Chemists. 1980; 10: 115-118.

6. Morton RL, Schroeder HE, Bateman KS, Chrispeels MJ, Armstrong E and Higgins TJ. Bean alpha-amylase inhibitor 1 in transgenic peas (Pisum sativum) provides complete protection from pea weevil (Bruchus pisorum) under field conditions. Proc Natl Acad Sci U S A. 2000; 97:3820-5. | Article | PubMed Abstract | PubMed Full Text

7. Kar SD, Basu S, Das NA, Ramkrishnan P, Mukherjee P, Nayak and Sen SK. Expression of cryIA(c) gene of Bacillus thuringiensis in transgenic chickpea plants inhibits development of podborer (Heliothis armigera) larvae. Trans Res. 1997; 6:177-185. | Article

8. Able JA, Rathus C and Godwin ID. The investigation of optimal bombardment parameters for transient and stable transgene expression in sorghum. In Vitro Cell Dev Biol. 2001; 37:341-348. | Article

9. Casas AM, Kononowicz AK, Zehr UB, Tomes DT, Axtell JD, Butler LG, Bressan RA and Hasegawa PM. Transgenic sorghum plants via microprojectile bombardment. Proc Natl Acad Sci U S A. 1993; 90:11212 6. | Article | PubMed Abstract | PubMed Full Text

10. Tadesse Y, Sagi L, Swennen R and Jacobs M. Optimisation of transformation conditions and production of transgenic sorghum (Sorghum bicolor) via microprojectile bombardment. Plant Cell Tissue Organ Cult. 2003; 75:1-18. | Article

11. Grootbroom AW, Mkhonza NI, O'Kennedy MM, Chakauya E, Kunert K and Chikwamba RK. Biolistic-mediated sorghum (Sorghum bicolor L. Moench) transformation via Mannose and Bialaphos based selection systems. Int. J. Bot. 2010; 6:89-94. | Article

12. Zhao ZY, Cai T, Tagliani L, Miller M, Wang N, Pang H, Rudert M, Schroeder $S$, Hondred D, Seltzer J and Pierce D. Agrobacterium-mediated sorghum transformation. Plant Mol Biol. 2000; 44:789-98. | Article I PubMed

13. Gurel S, Gurel E, Kaur R, Wong J, Meng L, Tan HQ and Lemaux PG. Efficient, reproducible Agrobacterium-mediated transformation of sorghum using heat treatment of immature embryos. Plant Cell Rep. 2009; 28:429-44. | Article | PubMed

14. Girijashankar V, Sharma HC, Sharma KK, Swathisree V, Prasad LS, Bhat BV, Royer M, Secundo BS, Narasu ML, Altosaar I and Seetharama N. Development of transgenic sorghum for insect resistance against the spotted stem borer (Chilo partellus). Plant Cell Rep. 2005; 24:513-22. I Article | PubMed

15. Alcantara EP, Aguda RM, Curtiss A, Dean DH and Cohen MB. Bacillus thuringiensis delta-endotoxin binding to brush border membrane vesicles of rice stem borers. Arch Insect Biochem Physiol. 2004; 55:16977. | Article | PubMed

16. Tang W, Chen H, Xu CG, Li XH, Lin YJ and Zhang QF. Development of insect-resistant transgenic indica rice with a synthetic $\mathrm{Cry} 1 \mathrm{C}^{*}$ gene. Mole Breed. 2006; 18:1-10. I Article

17. Bravo A, Gill SS and Soberon M. Mode of action of Bacillus thuringiensis Cry and Cyt toxins and their potential for insect control. Toxicon. 2007; 49:423-35. | Article | PubMed Abstract | PubMed Full Text

18. Gomez I, Pardo-Lopez L, Munoz-Garay C, Fernandez LE, Perez C, Sanchez $\mathrm{J}$, Soberon $\mathrm{M}$ and Bravo A. Role of receptor interaction in the mode of action of insecticidal Cry and Cyt toxins produced by Bacillus thuringiensis. Peptides. 2007; 28:169-73. | Article | PubMed

19. Sakai H, Howlader MT, Ishida Y, Nakaguchi A, Oka K, Ohbayashi K, Yamagiwa $\mathrm{M}$ and Hayakawa T. Flexibility and strictness in functional replacement of domain III of cry insecticidal proteins from Bacillus thuringiensis. J Biosci Bioeng. 2007; 103:381-3. | Article | PubMed

20. Cao J, Tang JD, Strizhov N, Shelton AM and Earle ED. Transgenic broccoli with high levels of Bacillus thuringiensis Cry1C protein control 
Ignacimuthu et al. Molecular Biology and Genetic Engineering 2014,

diamondback moth larvae resistant to Cry1A or Cry1C. Mol Breed. 1999; 5:131-141. I Pdf

21. Zaidi MA, Ye G, Yao H, You TH, Loit E, Dean DH, Riazuddin S and Altosaar I. Transgenic rice plants expressing a modified cry1Ca1 gene are resistant to Spodoptera litura and Chilo suppressalis. Mol Biotechnol. 2009; 43:232-42. | Article | PubMed

22. Gonzalez-Cabrera J, Farinos GP, Caccia S, Diaz-Mendoza M, Castanera P, Leonardi MG, Giordana B and Ferre J. Toxicity and mode of action of Bacillus thuringiensis Cry proteins in the Mediterranean corn borer, Sesamia nonagrioides (Lefebvre). Appl Environ Microbiol. 2006; 72:2594600. | Article | PubMed Abstract | PubMed Full Text

23. Bravo A, Miranda R, Gomez I and Soberon M. Pore formation activity of Cry1Ab toxin from Bacillus thuringiensis in an improved membrane vesicle preparation from Manduca sexta midgut cell microvilli. Biochim Biophys Acta. 2002; 1562:63-9. | Article | PubMed

24. Holsters M, de Waele D, Depicker A, Messens E, van Montagu M and Schell J. Transfection and transformation of Agrobacterium tumefaciens. Mol Gen Genet. 1978; 163:181-7. I Article I PubMed

25. Toriyama $\mathrm{K}$ and Hinata $\mathrm{K}$. Cell suspension and protoplast culture in rice. Plant Sci. 1985; 41:179-183. I Article

26. Jefferson RA, Kavanagh TA and Bevan MW. GUS fusions: betaglucuronidase as a sensitive and versatile gene fusion marker in higher plants. EMBO J. 1987; 6:3901-7. | Pdf | PubMed Abstract | PubMed Full Text

27. Kosugi S, Ohashi Y, Nakajima K and Arai Y. An improved assay for b-glucuronidase in transformed cells: methanol almost completely suppresses a putative endogenous glucuronidase activity. Plant Sci. 1990; 70: 133-140. | Article

28. Southern EM. Detection of specific sequences among DNA fragments separated by gel electrophoresis. J Mol Biol. 1975; 98:503-17. | Article | PubMed

29. Zhao ZY, Glassman K, Sewalt V, Wang N, Miller M, Chang S, Thompson T, Catron S, Wu E, Bidney D, Kedebe $Y$ and Jung R. Nutritionally improved transgenic sorghum. In: Vasil IK (eds) Plant biotechnology 2002 and beyond. Proceedings of the 10th IAPTC \& B Congress. Kluwer Academic Publishers, 2003; 413-416.

30. Masteller VJ and Holden DJ. The growth of and organ formation from callus tissue of sorghum. Plant Physiol. 1970; 45:362-4. | Article | PubMed Abstract | PubMed Full Text

31. Cai T, Daily B and Butler L. Callus induction and plant regeneration from shoot portions of mature embryos of high tannin Sorghums. Plant Cell Tiss Organ Cult. 1987; 9:245-252. I Article

32. $\mathrm{Ma} \mathrm{H}, \mathrm{Gu} \mathrm{M}$ and Liang $\mathrm{GH}$. Plant regeneration from cultured immature embryos of Sorghum bicolor (L.) Moench. Theor Appl Genet. 1987; 73:389-94. | Article | PubMed

33. Cai T and Butler L. Plant regeneration from embryogenic callus initiated from immature inflorescences of several high tannin sorghums. Plant Cell Tiss Organ Cult. 1990; 20:101-110. | Article

34. Kaeppler HF and Pedersen JF. Media effects on phenotype of callus cultures initiated from photoperiod-insensitive elite inbred sorghum lines. Maydica. 1996; 41:83-89. | Article

35. Premkumar A, Kannan P and Ignacimuthu S. Direct shoot regeneration from mature scutellum explants of Sorghum bicolour. Plant Cell Biotech. Mol. Biol. 2006; 7:129-134.

36. Raghuwanshi A and Birch RG. Genetic transformation of sweet sorghum. Plant Cell Rep. 2010; 29:997-1005. I Article I PubMed

37. Elkonin LA, Nosova ON and Italianskaya JV. Agrobacterium mediated genetic transformation of sorghum using tissue culture-based and pollen-mediated approaches. J Stress Physiol Biochem. 2012; 8:19970838. I Pdf

38. Liu G and Godwin ID. Highly efficient sorghum transformation. Plant Cell Rep. 2012; 31:999-1007. I Article I PubMed Abstract I PubMed Full Text

39. Battraw M and Hall TC. Stable transformation of Sorghum bicolor protoplasts with chimeric neomycin phosphotransferase II and betaglucuronidase genes. Theor App/ Genet. 1991; 82:161-8. | Article | PubMed

40. Casas AM, Kononowicz AK, Haan TG, Zhang L, Tomes DT, Bressan RA and Hasegawa PM. Transgenic sorghum plants obtained after microprojectile bombardment of immature inflorescences. In vitro Cell
Dev Biol. 1997; 33:92-100. | Article

41. Zhu H, Muthukrishnan S, Krishnaveni S, Wilde G, Jeoung JM and Liang $\mathrm{GH}$. Biolistic transformation of sorghum using a rice chitinase gene. J. Genet. Breed. 1998; 52:243-252.

42. Godwin I and Chikwamba R. Transgenic grain sorghum (Sorghum bicolour) plants via Agrobacterium. Improvement of Cereal quality by Genetic Engineering. 1994; 47-53. I Article

43. Jeoung JM, Krishnaveni S, Jayaraj J, Haying Yi H, Trick N, Muthukrishnan $\mathrm{S}$ and Liang GH. Agrobacterium mediated transformation of grain Sorghum. In: Seetharama N, Godwin I (eds) Sorghum tissue culture and transformation. Oxford and IBH PUb. 2002; 57-64.

44. Sticklen M. B. and H. Oraby. Shoot apical meristem: A sustainable explant for genetic engineering of cereal crops. In Vitro Cellular \& Developmental-PLANT. 2005; 41:187-200. | Article

45. Aragao FJL, Barros LMG, de Sousa MV, de Sa Grossi MF, Almeida ERP, Gander ES and Rech EL. Expression ofa methionine-rich storage albumin from the brazil nut (Bertholletia excelsa H.B.K., Lecythidaceae) in transgenic bean plants (Phaseolus vulgaris L., Fabaceae). Genet Mol Biol. 1999; 22:445-449. I Article

46. Hiei Y, Ohta S, Komari T and Kumashiro T. Efficient transformation of rice (Oryza sativa L.) mediated by Agrobacterium and sequence analysis of the boundaries of the T-DNA. Plant J. 1994; 6:271-82. | Article | PubMed

47. Ignacimuthu $S$ and Arockiasamy S. Agrobacterium-mediated transformation of an elite indica rice for insect resistance. Curr Sci. 2006; 90:829-835.

48. Carvalho CHS, Zehr UB, Gunaratna N, Anderson J, Kononowicz HH, Hodges TK and Axtell JD. Agrobacterium-mediated transformation of sorghum: factors that affect transformation efficiency. Genetics and Molecular Biology. 2004; 27:259-269. I Article

49. Shitara H, Sato A, Hayashi J, Mizushima N, Yonekawa H and Taya C. Simple method of zygosity identification in transgenic mice by real-time quantitative PCR. Transgenic Res. 2004; 13:191-4. I Article I PubMed

50. Sridevi GC, Parameswari P, Rajamuni $K$ and Veluthambi. Identification of hemizygous and homozygous transgenic rice plants in $\mathrm{T} 1$ generation by DNA blot analysis. Plant Biotechnol. 2006; 23:531-534. | Article

51. Jotwani MG and Young WR. Recent developments in chemical control of insect pests of sorghum. In: Rao NGP, House LR( eds) Sorghum in Seventies, Oxford \& IBH Publishing, New Delhi, India. 1972; 251-256.

52. Sharma HC, Dhillon MK, Kibuka J and Mukuru SZ. Plant defense responses to sorghum spotted stem borer, Chilo partellus under irrigated and drought conditions. ejournal.icrisat.org. 2005; 1.

53. Brietler JC, Cordero MJ, Royer M, Meynard D, San Segundo B and Guiderdoni $E$. The $-689 /+197$ region of the maize protease inhibitor gene directs high level, wound-inducible expression of the cry1B gene which protects transgenic rice plants from stem borer attack. $\mathrm{Mol}$ Breed. 2001; 7:259-274. | Article

54. Datta K, Vasquez A, Tu J, Torrizo L, Alam MF, Oliva N, Abrigo E, Khush GS and Datta SK. Constitutive and tissue-specific differential expression of $\operatorname{cry} 1 A(b)$ gene in transgenic rice plants conferring resistance to rice insect pests. Theor Appl Genet. 1998; 97:20-30.

55. Maqbool SB, Raizuddin S, Loc TN, Gatehouse AMR, Gatehouse JA and Christou P. Expression of multiple insecticidal genes confers broad resistance against a range of different rice pests. Mol Breed. 2001; 7:85-93. | Article

56. Ye SH, Chen S, Zhang F, Wang W, Tian Q, Liu JZ, Chen F and Bao JK. Transgenic tobacco expressing Zephyranthes grandiflora agglutinin confers enhanced resistance to aphids. Appl Biochem Biotechnol. 2009; 158:615-30. I Article I PubMed

\begin{tabular}{l} 
Citation: \\
Ignacimuthu S and Premkumar A. \\
Development of transgenic Sorghum bicolor \\
(L.) Moench resistant to the Chilo partellus \\
(Swinhoe) through Agrobacterium-mediated \\
transformation. Mol Biol Genet Eng. 2014; 2:1. \\
http://dx.doi.org/10.7243/2053-5767-2-1 \\
\hline
\end{tabular}

